\title{
Fibroblast-derived Gremlin1 localises to epithelial cells at the base of the intestinal crypt
}

\author{
Louise R. Dutton ${ }^{1, *}$, Owen P. Hoare ${ }^{2, *}$, Amy M.B. McCorry ${ }^{2, *}$, Keara L. Redmond ${ }^{2}$, \\ Noor Eisa Adam ${ }^{1,3}$, Shannon Canamara ${ }^{1,4}$, Victoria Bingham², Paul B. Mullan ${ }^{2}$, Mark \\ Lawler ${ }^{2}$, Philip D. Dunne ${ }^{2, * *}$ and Derek P. Brazil ${ }^{1, * *}$ \\ ${ }^{1}$ Wellcome-Wolfson Institute for Experimental Medicine, Queen's University Belfast, Belfast, Northern Ireland, UK \\ ${ }^{2}$ Centre for Cancer Research and Cell Biology, Queen's University Belfast, Belfast, Northern Ireland, UK \\ ${ }^{3}$ Mohammed Bin Rashid University of Medicine and Health Sciences, Dubai Healthcare City, United Arab Emirates \\ ${ }^{4}$ Indonesia International Institute for Life-Sciences, University of East Jakarta, Jakarta Timur, Indonesia \\ *These authors contributed equally to this work \\ *** Co-senior authors \\ Correspondence to: Derek P. Brazil, email: d.brazil@qub.ac.uk \\ Philip D. Dunne, email: p.dunne@qub.ac.uk \\ Keywords: Gremlin 1; colorectal cancer; fibroblasts; stroma; pathology \\ Received: February 25, $2019 \quad$ Accepted: June 19, $2019 \quad$ Published: July 23, 2019 \\ Copyright: Dutton et al. This is an open-access article distributed under the terms of the Creative Commons Attribution License 3.0 (CC BY \\ 3.0), which permits unrestricted use, distribution, and reproduction in any medium, provided the original author and source are credited.
}

\section{ABSTRACT}

Gremlin1 (GREM1) is a secreted glycoprotein member of the differential screeningselected gene in aberrant neuroblastoma (DAN) family of bone morphogenetic protein (BMP) antagonists, which binds to BMPs preventing their receptor engagement. Previous studies have identified that stage II colorectal cancer (CRC) patients with high levels of GREM1 gene expression in their tumour tissue have a poorer prognosis. Using a series of in silico and in situ methodologies, we demonstrate that GREM1 gene expression is significantly higher $(p<0.0001)$ in CRC consensus molecular subtype 4 (CMS4), compared to the other CMS subtypes and correlates $(p<0.0001)$ with levels of cancer-associated fibroblasts (CAFs) within the CRC tumour microenvironment (TME). Our optimised immunohistochemistry protocol identified endogenous GREM1 protein expression in both the muscularis mucosa and adjacent colonic crypt bases in mouse intestine, in contrast to RNA expression which was shown to localise specifically to the muscularis mucosa, as determined by in situ hybridisation. Importantly, we demonstrate that cells with high levels of GREM1 expression display low levels of phospho-Smad1/5, consistent with reduced BMP signalling. Taken together, these data highlight a novel paracrine signalling circuit, which involves uptake of mature GREM1 protein by colonic crypt cells following secretion from neighbouring fibroblasts in the TME.

\section{INTRODUCTION}

Gremlin1 (GREM1) is a conserved 184 aa glycoprotein antagonist of bone morphogenetic protein (BMP) signalling which regulates organogenesis and differentiation $[1,2]$. GREM1 has also been reported to signal via BMP-independent mechanisms including vascular endothelial growth factor receptor 2 (VEGFR2), Slit proteins and fibrillin [3]. Tight regulation of stem cell homeostasis in the colonic crypt requires polarized, opposing expression gradients of BMP and Wnt (Wingless/ Integrated), regulated by BMP antagonists such as GREM1 and Noggin along the crypt vertical axis [4], which is thought to be a key barrier to colorectal tumorigenesis. Consistently, GREM1 overexpression has been linked to a range of cancers, including colorectal cancer (CRC) [510], with mutations affecting BMP signalling occurring in a large number of CRCs [11].

Molecular profiling in CRC has identified four consensus molecular subtypes (CMS) [12]; CMS1 is associated with microsatellite instability (MSI) and a strong immune response, CMS2 and CMS3 are epithelialrich subtypes, characterised by Wnt signalling and metabolic dysregulation, and CMS4, the "mesenchymal/ 
EMT" subtype, is linked with stromal infiltration, angiogenesis, TGF- $\beta$ activation and the lowest relapsefree and overall patient survival [12]. Dysregulation of BMP signalling is implicated in disrupted epithelial phenotypes, possibly through epithelial-to-mesenchymal transition (EMT) [13] and cancer cell proliferation [1416]. Consistently, increased epithelial-specific GREM1 gene and protein expression is observed in tumour tissue from patients with hereditary mixed polyposis syndrome (HMPS), caused by a single $40-\mathrm{kb}$ genetic duplication on chromosome 15 in the GREMI enhancer region [17]. Furthermore, GREM1 overexpression has also been identified in epithelial cells of more common sporadic colorectal traditional serrated adenomas (TSAs) [18] at the desmoplastic invasive front [13].

In this study, we use in silico and in situ methods to confirm the prognostic value of GREM1 and provide a comprehensive assessment of the cellular source of RNA and protein, which may differ from the final protein localisation of GREM1 in the intestine.

A
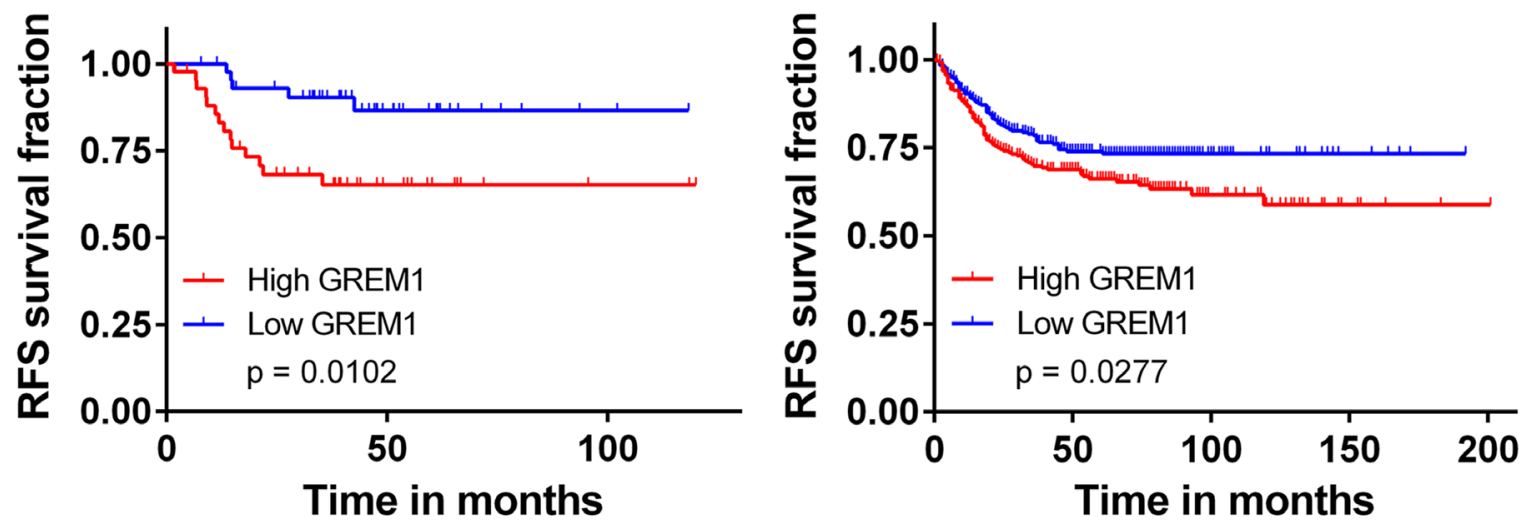

B
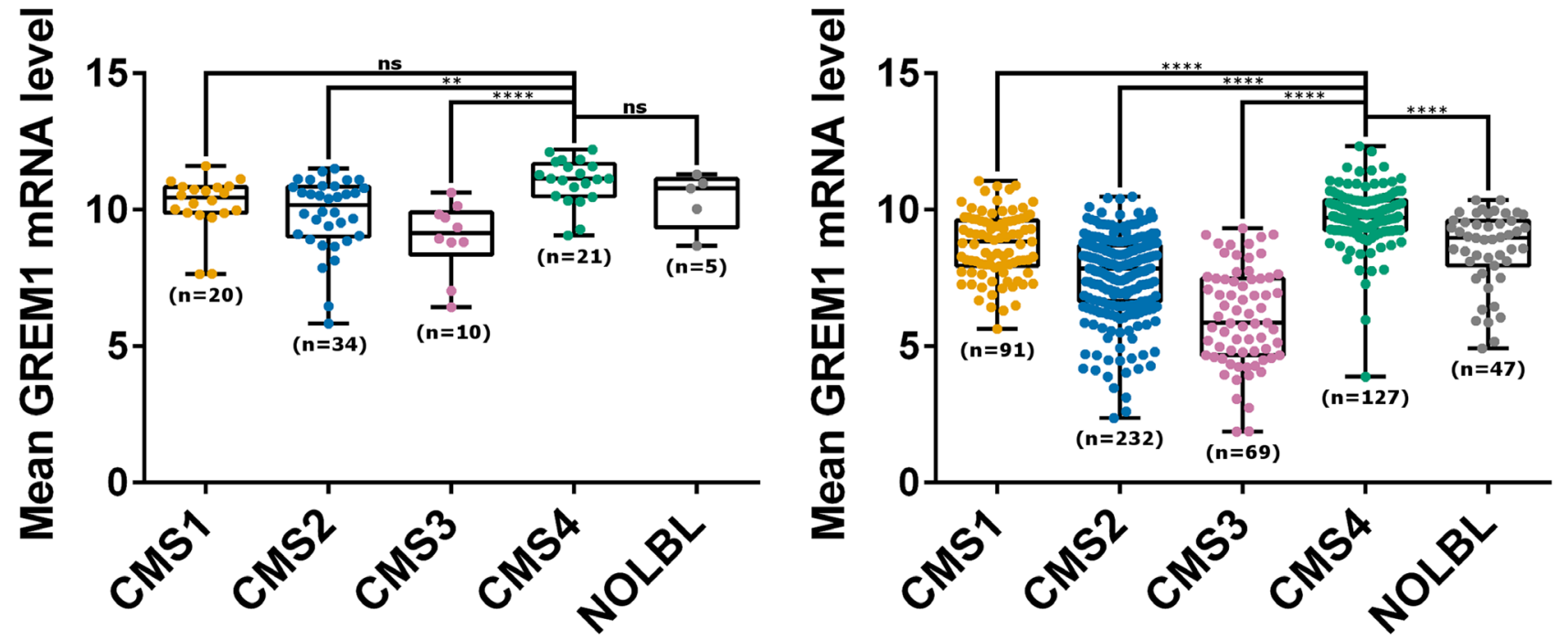

Figure 1: GREM1 mRNA levels correlate with prognosis, CMS subtypes and cancer cell types. (A) Kaplan-Meier curves for GSE33113 (left; $n=90,45$ patients per group) which contains data from primary tumour resections of stage II CRC patients, and GSE39582 (right; $n=557$ (low, $n=279$; high, $n=278$ ), which contains primary tumour resections of stage I-IV CRC patients, showing that patients with high expression (above median; red) of GREM1 mRNA have a poorer relapse-free survival compared to those with a low expression (blue; $p=$ 0.0102 and $p=0.0277$ respectively). (B) Boxplots showing GREM1 mRNA levels within each of the four CMS subtypes (CMS1-4) together with samples that were unclassified with no CMS label (NOLBL) in GSE33113 (left) and GSE39582 (right). CMS4 patients displayed the highest level of GREM1 mRNA compared to other subtypes (ns non-significant, ${ }^{* *} p<0.01,{ }^{* * *} p<0.001,{ }^{* * * *} p<0.0001$ ). 


\section{RESULTS}

\section{Clinical relevance of $G R E M 1$ gene expression in CRC patients}

We confirmed the association between high levels of GREM1 mRNA and disease recurrence, using a previously described cohort of stage II CRC [19] (GSE33113 [20]; $n=90$; Figure 1A left), in addition to validation of these findings in a further independent CRC cohort (GSE39582 [21]; $n=557$; Figure 1A right). Increased levels of epithelial-specific GREM1 mRNA and protein expression have previously been identified in intestinal tissue from HMPS patients [17]. This predisposition is very rare, therefore we analysed GREMI mRNA levels across five non-HMPS CRC transcriptional datasets that had been stratified into CMS subtypes [12], and identified significantly higher quantities of GREM1 mRNA in the fibroblast-rich CMS4 subtype compared to CMS1-3 (Figure 1B, Supplementary Figure 1).

\section{Cellular source of GREM1 gene expression in CRC}

We and others have previously highlighted the association between CMS4, high levels of cancerassociated fibroblasts (CAFs), and poor prognosis in CRC [22-25] Therefore, we next set out to delineate the cellular-specific source of GREMI from within the TME of stromal-rich CMS4 tumours. Previously published data suggested that GREM1 protein expression was associated with the epithelial compartment of the TME in HMPS and TSA tissue [19]. In contrast, using a cohort of CRC tissue sorted into purified pools according to their cellular lineages (GSE39396 [26]; endothelial, epithelial, leukocytes and fibroblasts), we now demonstrate that GREMI mRNA levels are significantly associated with CAFs compared to other components of the TME $(p<$ 0.0001; Figure 2A). In addition, in non-cancer tissue we find that GREM1 mRNA is higher in smooth muscle cells compared to any other cellular lineage or tissue (Supplementary Figure 2A). Consistent with these data, we demonstrated that GREM1 mRNA levels are significantly higher in CRC primary tumour tissue, which contains all components of the TME, compared to epithelial stem cells, which are devoid of other TME lineages such as fibroblasts (GSE33114 [20] $p$ $<0.0001$; Figure 2B). These results were validated in an additional independent cohort (GSE100550 [27]), showing GREM1 mRNA is significantly higher in CRC tumour tissue compared to either CRC spheroids, organoids or cell lines (all $p<0.0001$; Supplementary Figure 2B). Furthermore, a direct correlation was demonstrated between GREMI mRNA levels and both fibroblast activation protein (FAP) mRNA (Pearson $r$ $=0.7117, p<0.0001$ Figure $2 \mathrm{C}$ left) or ESTIMATE
StromalScore (Pearson $r=0.7448, p<0.0001$; Figure $2 \mathrm{C}$ right) in transcriptional data from primary CRC tumour tissue (GSE39582 [23]).

\section{Contrast between Grem1 protein localisation and source of transcript}

Other reports have identified GREM1 expression in basal cell cancer CAFs [28]. Our data strongly supports an association of GREM1 mRNA expression with the CMS4 subtype of CRC and that fibroblasts are the most likely cell source of GREM1 in these tumours (Figures 1 and 2). Importantly, these data suggest that the prognostic value associated with GREM1 gene expression is likely a direct result of its correlation to fibroblast levels within this otherwise poor-prognostic subtype.

Given that GREM1 is a secreted protein that acts as an antagonist of BMP signalling in the extracellular space [3], an immunohistochemistry (IHC) assay was developed to identify the pattern of Grem1 protein expression in mouse colon to be run in parallel with gene expression using RNA in situ hybridisation (RNAISH). Consistent with our previous data [29] and in line with data presented here (Figure 2), Grem 1 mRNA was almost exclusively localised in the muscularis mucosa in wild-type mice (Figure 3A left). In contrast, Grem1 protein staining was more diffuse, and was detected in both the muscularis mucosa and the base of the colonic crypts (Figure 3A right). Importantly, to fully confirm the specificity of this staining, we utilised intestinal tissue from a Grem 1 genetic knockout mouse model (Grem $1^{-1-}$ [29]) (Supplementary Figure 3A and 3B), or IgG isotype controls (data not shown), where no signal was detected for either Grem1 RNA-ISH or IHC compared to wildtype mice. Further detailed analysis indicated that Grem 1 protein was localised in the crypt base columnar cells $(\mathrm{CBCC})$, Paneth cells $(\mathrm{P})$ and transit-amplifying cells (TA) in mouse colon (Figure 3B). Consistent with high levels of Grem1 at the base of the colonic crypts, low levels of pSmad $1 / 5$ staining were evident in these cells, indicative of antagonised BMP signalling in this compartment (Figure 4A). In contrast, at the tips of the villi toward the intestinal lumen where Grem 1 protein staining was barely detected, levels of pSmad $1 / 5$ were higher, suggestive of stronger BMP signalling in these cells (Figure 4B). A significantly higher number of Grem1-positive cells were detected in the crypts versus villi tips, with a reciprocally higher number of pSmad $1 / 5$ positive cells detected in the villi tips versus crypts (Figure 4C, Supplementary Figure 4).

\section{DISCUSSION}

Comparison of Grem 1 mRNA and protein highlights the differential pattern of staining, where Greml is being transcribed by fibroblasts within the muscularis 
muscosa, and then secreted from this layer, before finally localising to the cells at the lower levels of the colonic crypt (summarised in Figure 5). Our data indicates a gradient effect, where the highest levels of Grem 1 protein are observed at the bottom of the crypt directly proximal to the muscularis muscosa, and becomes more diffuse outside of the crypt base towards the luminal surface. The exact mechanisms of Grem 1 protein uptake into colon crypt cells remains to be determined.
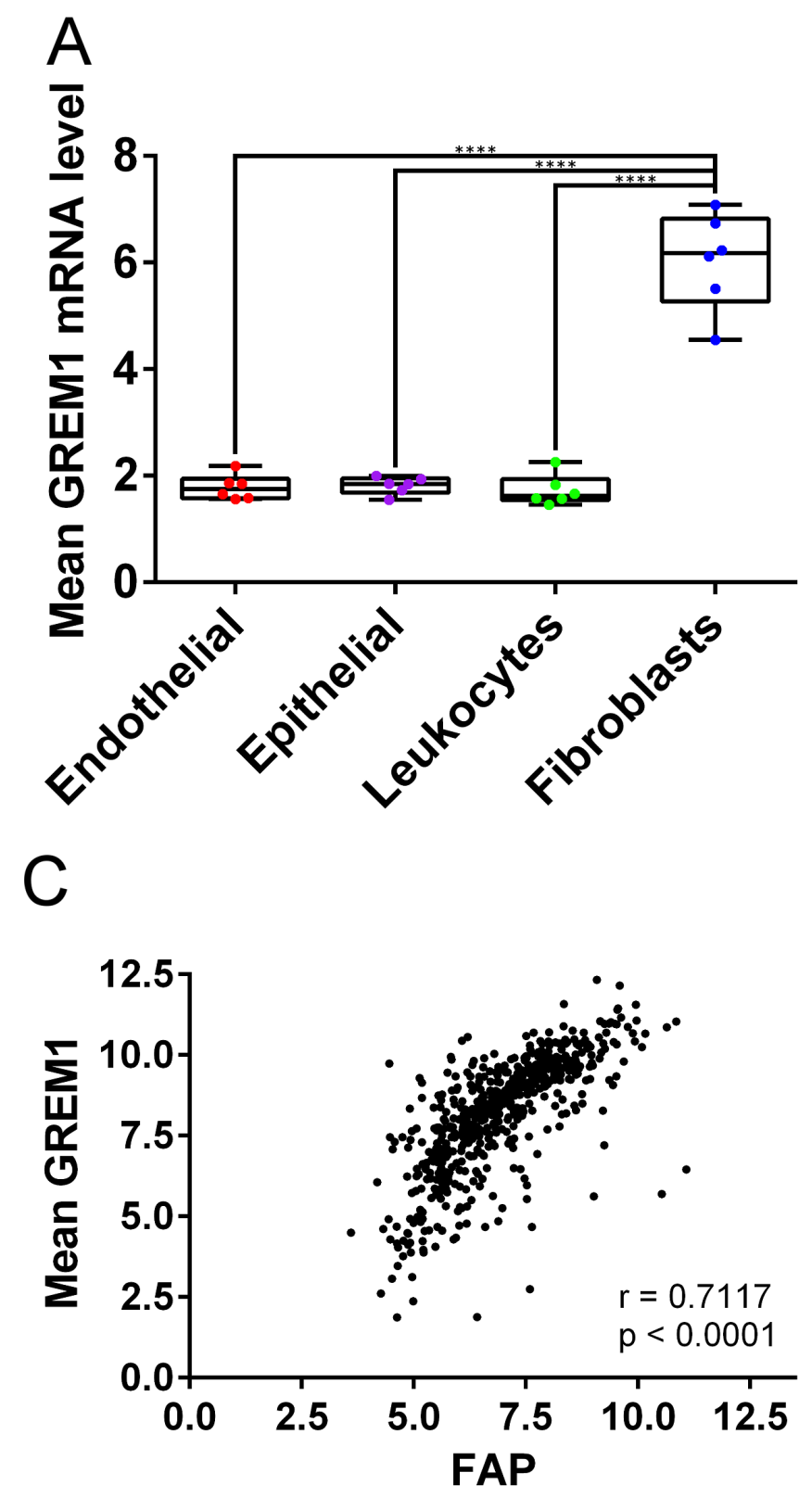

In summary, using a number of independent datasets we demonstrate that Grem 1 mRNA predominantly originates in fibroblast/smooth muscle lineages. Following translation to protein, it appears to be secreted and potentially taken up into cells that do not stain for Grem 1 mRNA. Grem1 appears to mediate antagonism of BMP signalling in these cells, based on the low levels of $\mathrm{pSmad} 1 / 5$ detected in the colonic crypts (Figure 4). Data presented here provides a new insight into the mechanism
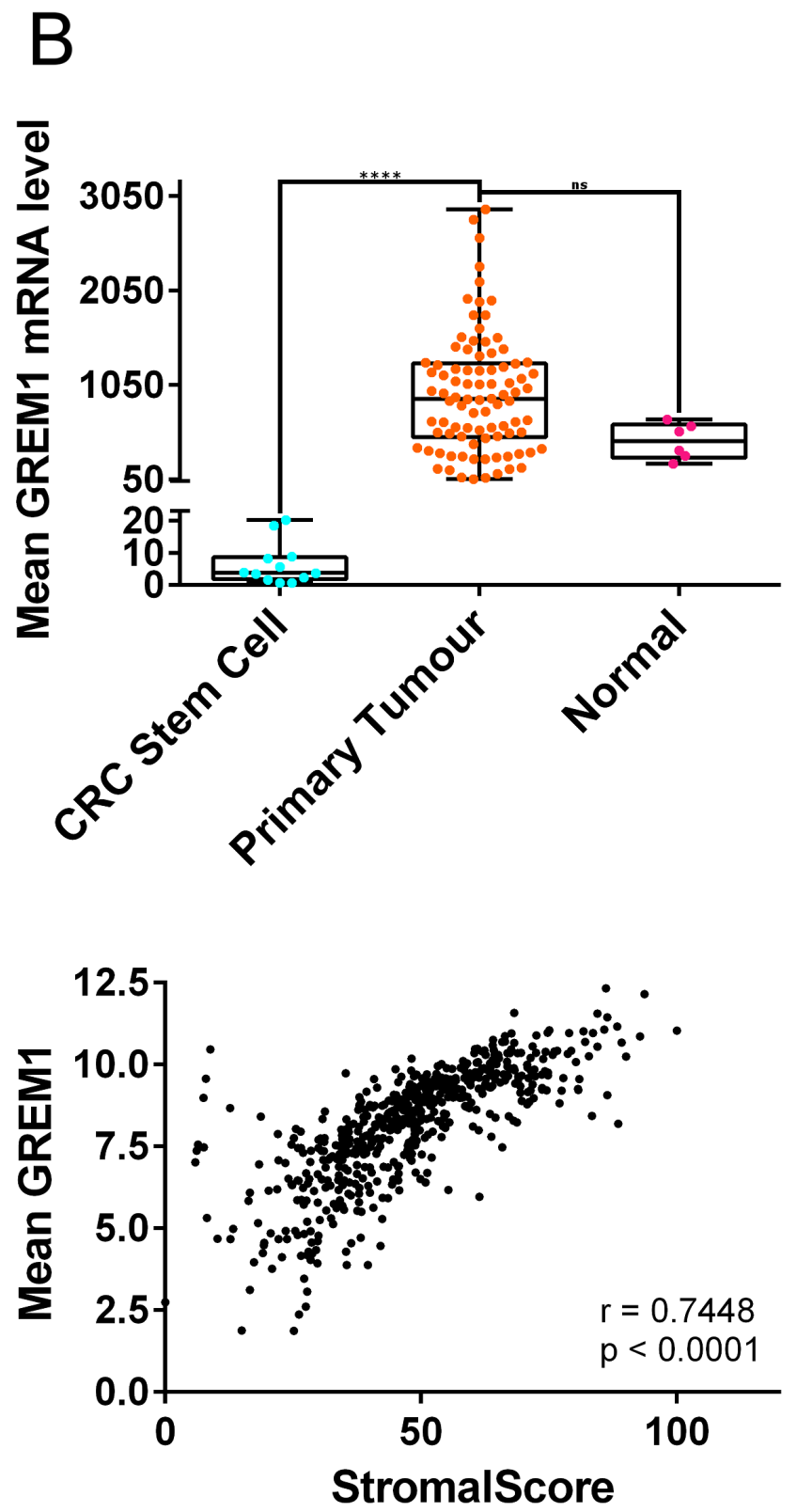

Figure 2: GREM1 mRNA levels in cell populations and tumour tissue, and correlations with $F A P$ expression and StromalScore. (A) In GSE39396, which contains data from six fresh colon tumours sorted using fluorescence-activated cell sorting (FACS), fibroblasts contain more GREM1 mRNA than endothelial cells, epithelial cells and leukocytes (all $p<0.0001$ ). (B) In GSE33114, GREM1 mRNA levels are significantly higher in primary tumours compared to CRC stem cells $(p<0.0001)$ and borderline significant compared to normal tissue $(p=0.0744)$. (ns non-significant, ${ }^{* * * *} p<0.0001$ ). (C) Scatterplot (left) showing positive correlation between GREM1 mRNA levels and FAP expression in GSE39582 (Pearson $r=0.7117, p<0.0001$ ). GREM1 mRNA levels also positively correlated with StromalScore (right; Pearson $r=0.7448, p<0.0001$ ). 

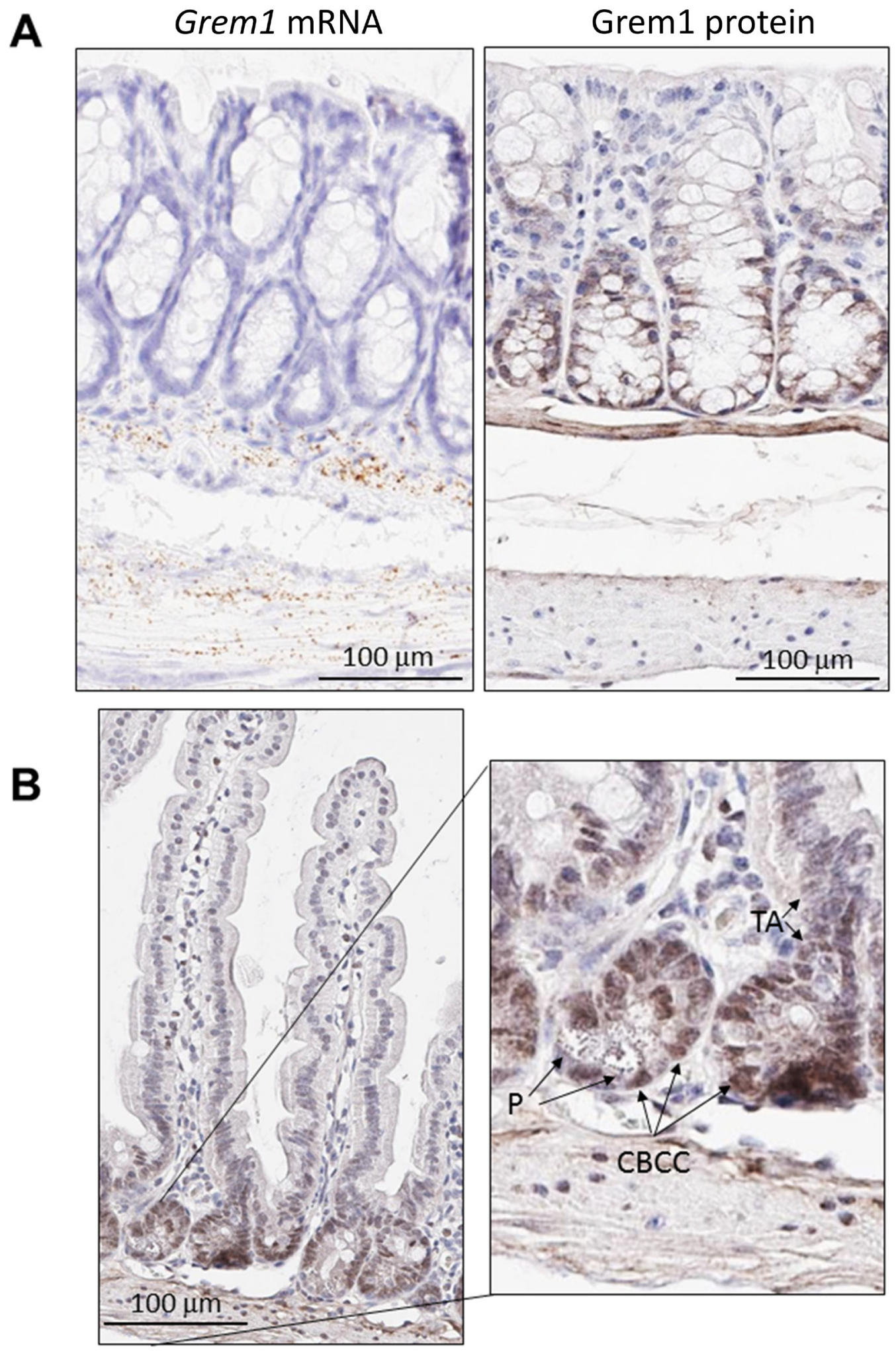

Figure 3: Distinct pattern of endogenous Grem1 expression in mouse colon. Sections $(5 \mu \mathrm{m})$ from FFPE colon samples $(n=4)$ from wild-type or Grem $1^{-/}$mice were processed for in situ hybridisation (A left) and immunohistochemistry (A right; B.) as described in Methods. Positive Grem 1 mRNA and protein staining was imaged using DAB (brown) and sections were counterstained using haematoxylin and imaged using PathXL. (A) Grem 1 mRNA is visible as brown, punctate staining in the muscularis mucosa layer. Scale bars $100 \mu \mathrm{m}$. (B) Grem1 protein staining is evident as brown staining in the muscularis layer and the base of the colonic crypts (left; scale bar $100 \mu \mathrm{m}$ ). Grem1 protein staining in the musclaris layer as well as cells of the colonic crypt. CBCC, crypt base columnar cells; P, Paneth cells; TA, transit-amplifying cells. 

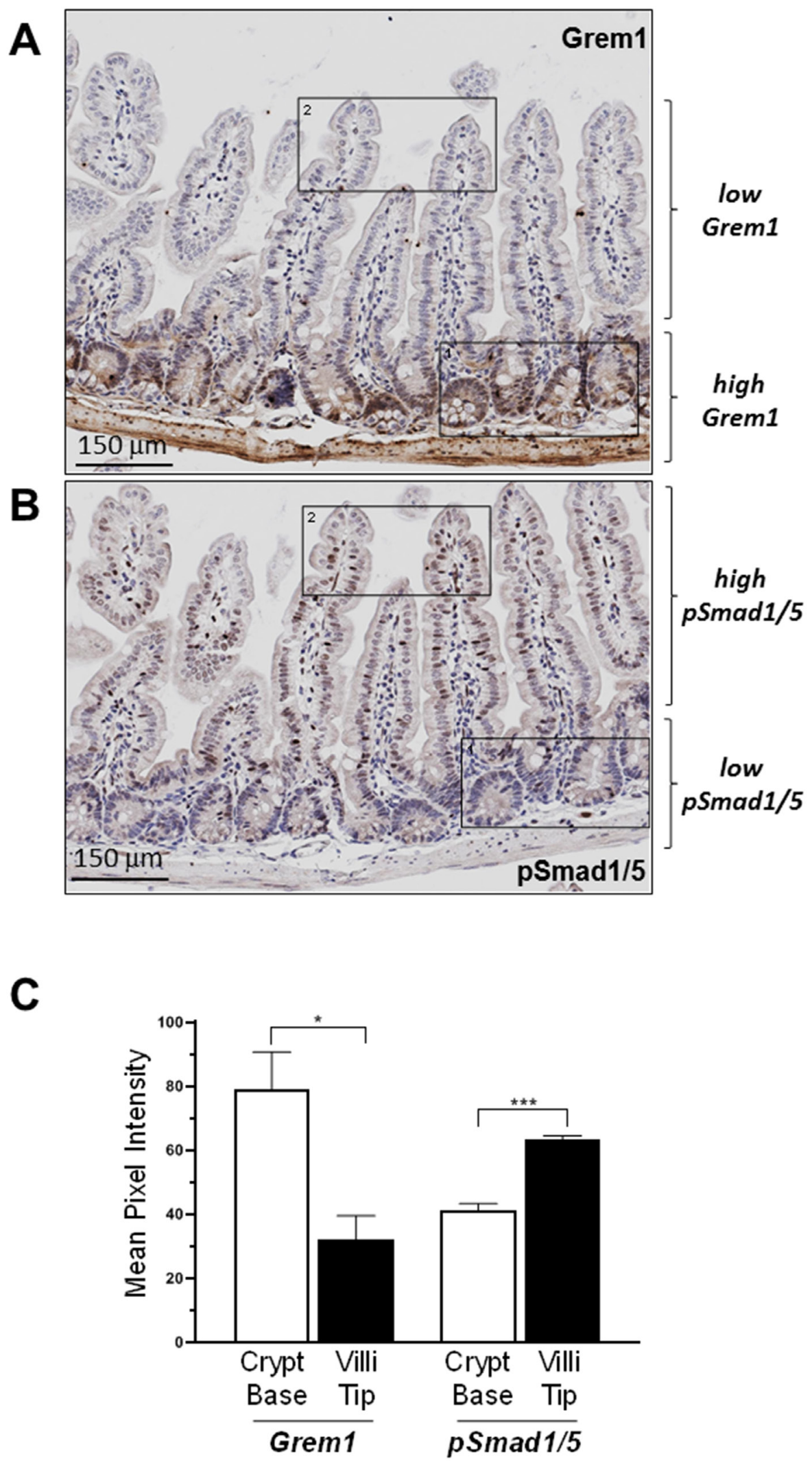

Figure 4: Inverse relationship between expression of Grem1 protein and pSmad1/5 staining in mouse intestine. Sequential FFPE sections (5 $\mu \mathrm{m}$ ) of mouse intestine were stained for Grem1 (A) or pSmad1/5 (B) as described in Methods. (C) Positively stained cells (empty bars) or villi tips (filled bars) were quantified in the indicated regions using Image J and data were plotted as mean pixel intensity $-/+\operatorname{SEM}\left(n=3\right.$ mice, 3 independent regions of intestine quantified per mouse). ${ }^{*} p<0.05,{ }^{* * *} p<0.001$ using two-way ANOVA and Bonferroni post hoc test. 


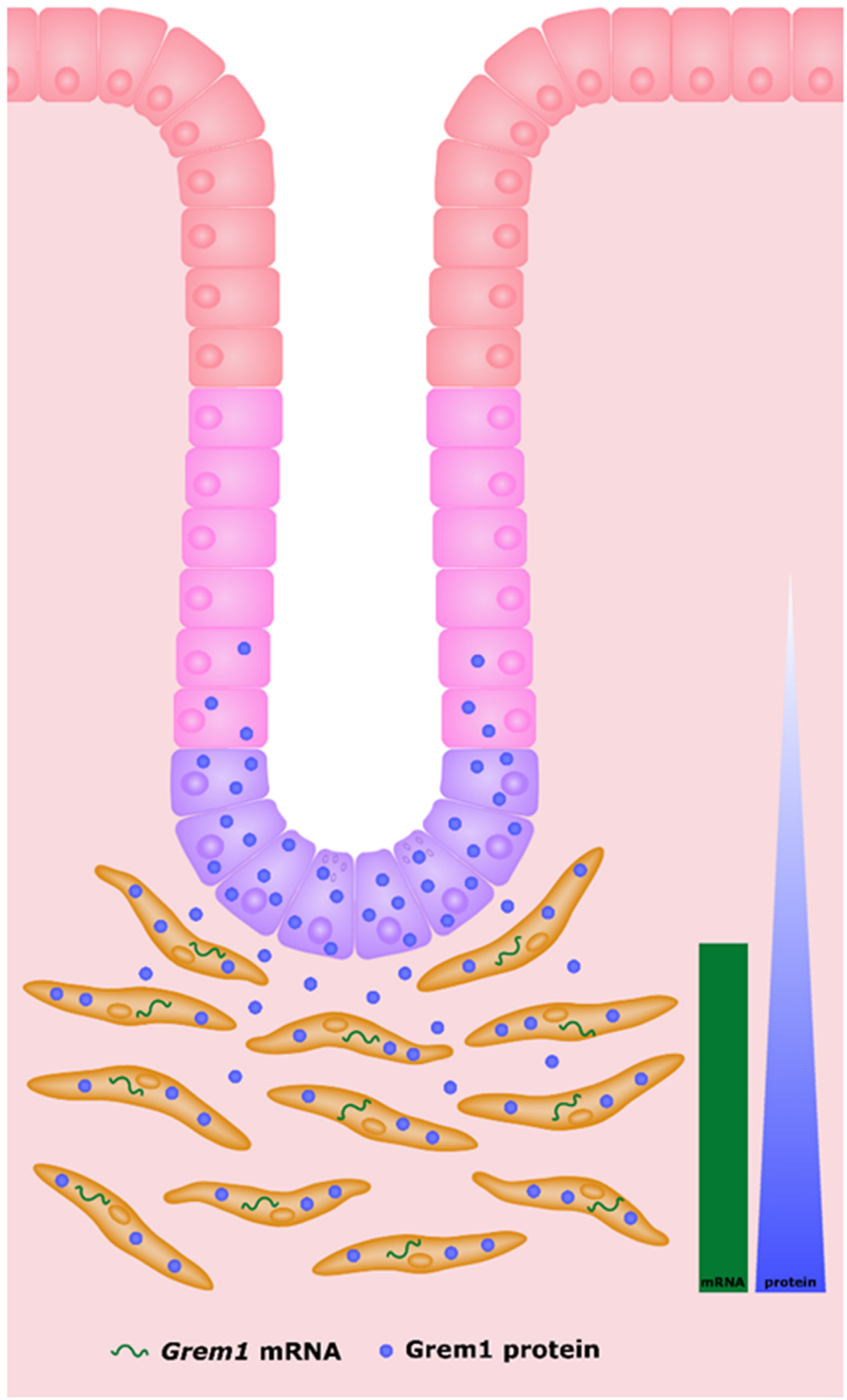

Figure 5: Schematic highlighting the source of Grem1 mRNA and protein in mouse intestine. Grem1 mRNA (green) is produced by fibroblasts (orange) in the muscularis layer. Grem1 protein (blue) produced in these cells is then secreted and taken up by cells of the colon crypts (transit-amplifying cells (pink), crypt base columnar cells (purple) and Paneth cells (purple). The levels of Grem1 protein decrease as cells mature up towards the distal epithelial layer (red) nearest the lumen (white). 
underlying Grem 1 signalling in the intestine and provides evidence for the presence of a novel paracrine signalling loop between fibroblasts and epithelial cells to maintain the stem cell niche of the colonic crypt.

\section{MATERIALS AND METHODS}

\section{Transcriptional analyses}

For GSE33113 [20], consisting of stage II primary tumour resections $(n=90)$, and GSE39582 [23], consisting of stage I-IV primary tumour resections $(n=557)$, RMA normalised transcriptional data and relevant clinical information were obtained from Synapse ID syn2623706 (https://www.synapse.org/). For GSE39396 [26], which contains data from four cell populations isolated from fresh colon tumours $(n=6)$, and GSE33114 [20], which contains the primary tumour data from GSE33113 combined with data from colon cancer stem cells $(n=12)$, data was obtained as series matrices from GEO (https://www.ncbi. nlm.nih.gov/geo/). StromalScores were calculated using the estimate package (v1.0.13) [30] in R (v3.5.1).

\section{Survival analyses, correlations and boxplots}

Kaplan-Meier curves with log-rank test, scatterplots with Pearson's correlation coefficient and boxplots with ANOVA were generated using GraphPad Prism (v6.01; La Jolla, CA, USA).

\section{In situ hybridisation (ISH)}

ISH was performed on Formalin-Fixed ParaffinEmbedded (FFPE) sections $(5 \mu \mathrm{m})$ of wild-type and Grem 1 homozygous genetic knockout $\left(\right.$ Grem $\left.^{-/-}\right)$mouse colon, using the RNAscope 2.0 kit (Advanced Cell Diagnostics, Hayward, CA, USA) to detect Grem1 mRNA (Mm-Grem1, catalog no. 314741) [29]. Slides were scanned using an Aperio AT2 scanner and uploaded to the PathXL digital pathology suite (Belfast, Northern Ireland, UK).

\section{Immunohistochemistry (IHC)}

IHC was performed on wild-type and Grem $1^{-/}$ colon using the VectaStain Goat IgG kit according to manufacturer's instructions (Vector Laboratories, Burlingame, CA, USA). Sections $(5 \mu \mathrm{m})$ were deparaffinised on a Leica Bond RX system. Sections were washed and then epitope retrieval performed. Sections were washed in PBS- $0.1 \%$ Triton-X, quenched with $3 \%(\mathrm{v} / \mathrm{v}) \mathrm{H}_{2} \mathrm{O}_{2}$ in PBS-0.1\% Triton-X for $10 \mathrm{~min}$ at RT, washed, blocked with $10 \%(\mathrm{v} / \mathrm{v})$ rabbit serum in PBS-0.1\% Triton-X for $60 \mathrm{~min}$ at RT in a humidified, dark chamber, and incubated with anti-Grem1 antibody
(R\&D Systems AF956, raised in goat, 1:250 in PBS-0.1\% Triton-X,) or anti-pSmad1/5 Ser463/Ser465 antibody (Thermo Fisher Scientific 31H14L11, raised in rabbit, $1: 175$ in PBS- $0,1 \%$ Triton-X) overnight at $4^{\circ} \mathrm{C}$. Goat $\mathrm{IgG}$ and rabbit $\mathrm{IgG}$ isotype controls were also included at the same dilutions. Following washing with PBS-0.1\% Triton-X, secondary anti-goat biotin antibody $(1: 250)$ was added for $90 \mathrm{~min}$ at RT. After washing, the Avidin Biotin Complex (ABC) reagent was added for $30 \mathrm{~min}$ at RT. Detection was performed using 3,3'-diaminobenzidine kit (DAB Substrate Kit, SK-4100, Vector Laboratories) for 3-7 min, and reactions were stopped using $\mathrm{ddH}_{2} 0$. Slides were counterstained on a Sakuara Autostainer using a standard protocol and haematoxylin for $30 \mathrm{sec}$, and a coverslip added. Slides were scanned using an Aperio AT2 scanner and uploaded to PathXL digital pathology suite.

\section{Quantification of immunohistochemistry staining}

Sequential FFPE sections ( $5 \mu \mathrm{m})$ were stained for Grem 1 or $\mathrm{pSmad} 1 / 5$ as above. Images were captured on PathXL and quantification of Grem 1 and Smad1/5 staining was carried out on programmes Fiji [31] and ImageJ [32]. Cells were selected within the defined area and the MultiPoint tool was used to calculate Mean Pixel Intensity for each cell. Three mice per group were analysed, with three independent images quantified per mouse. Data was analysed on GraphPad Prism (V8.1.0) and statistical significance determined using two-way ANOVA with Bonferroni post hoc test.

\section{Author contributions}

LD: data generation, manuscript writing and editing and generation of figures; $\mathrm{OH}$ : data generation; AMBM: data generation, manuscript editing and generation of figures; KLR: data generation, manuscript editing; NEA: data generation; SC: quantitation of Grem1 and $\mathrm{pSmad} 1 / 5$ immunohistochemistry; VB: generation of ISH and IHC data; PBM: data generation, manuscript editing; ML: project supervision; PDD: project design, planning, supervision, data generation, manuscript writing and editing; DPB: project design, planning, supervision, data generation, manuscript writing and editing.

\section{ACKNOWLEDGMENTS}

The authors thank Liza Colhoun for expert technical assistance. We are grateful to Dr. Hayley Davis and Prof. Simon Leedham (University of Oxford) for helpful discussions and providing samples from Villin-Grem1 mice.

\section{CONFLICTS OF INTEREST}

None. 


\section{FUNDING}

LD is funded by a Northern Ireland Department for Education studentship. AMBM is funded by a Cancer Research UK non-clinical studentship. ML is supported by Cancer Research UK, the Medical Research Council (UK) and the Health Data Research UK programme. PD is supported by Cancer Research UK and the Medical Research Council (UK). DPB is funded by MRC and NC3Rs.

\section{REFERENCES}

1. Hino J, Kangawa K, Matsuo H, Nohno T, Nishimatsu S. Bone morphogenetic protein-3 family members and their biological functions. Front Biosci. 2004; 9:1520-9. https:// doi.org/10.2741/1355. [PubMed]

2. Church RH, Krishnakumar A, Urbanek A, Geschwinder S, Meneely J, Bianchi A, Brazil DP. Gremlin1 preferentially binds to Bone Morphogenetic Protein-2 (BMP-2) and BMP-4 over BMP-7. Biochem J. 2015; 466:55-68. https://doi. org/10.1042/BJ20140771. [PubMed]

3. Brazil DP, Church RH, Surae S, Godson C, Martin F. BMP signalling: agony and antagony in the family. Trends Cell Biol. 2015; 25:249-64. https://doi.org/10.1016/j. tcb.2014.12.004. [PubMed]

4. Kosinski C, Li VS, Chan AS, Zhang J, Ho C, Tsui WY, Chan TL, Mifflin RC, Powell DW, Yuen ST, Leung SY, Chen X. Gene expression patterns of human colon tops and basal crypts and BMP antagonists as intestinal stem cell niche factors. Proc Natl Acad Sci U S A. 2007; 104:1541823. https://doi.org/10.1073/pnas.0707210104. [PubMed]

5. Namkoong H, Shin SM, Kim HK, Ha SA, Cho GW, Hur SY, Kim TE, Kim JW. The bone morphogenetic protein antagonist gremlin 1 is overexpressed in human cancers and interacts with YWHAH protein. BMC Cancer. 2006; 6:74. https://doi.org/10.1186/1471-2407-6-74. [PubMed]

6. Sha G, Zhang Y, Zhang C, Wan Y, Zhao Z, Li C, Lang J. Elevated levels of gremlin-1 in eutopic endometrium and peripheral serum in patients with endometriosis. Fertil Steril. 2009; 91:350-8. https://doi.org/10.1016/j. fertnstert.2007.12.007. [PubMed]

7. Sneddon JB, Zhen HH, Montgomery K, van de Rijn M, Tward AD, West R, Gladstone H, Chang HY, Morganroth GS, Oro AE, Brown PO. Bone morphogenetic protein antagonist gremlin 1 is widely expressed by cancerassociated stromal cells and can promote tumor cell proliferation. Proc Natl Acad Sci U S A. 2006; 103:148427. https://doi.org/10.1073/pnas.0606857103. [PubMed]

8. Yin M, Tissari M, Tamminen J, Ylivinkka I, Rönty M, von Nandelstadh P, Lehti K, Hyytiäinen M, Myllärniemi M, Koli K. Gremlin-1 is a key regulator of the invasive cell phenotype in mesothelioma. Oncotarget. 2017; 8:98280-97. https://doi.org/10.18632/oncotarget.21550. [PubMed]

9. Sato M, Kawana K, Fujimoto A, Yoshida M, Nakamura H, Nishida H, Inoue T, Taguchi A, Takahashi J, Adachi K,
Nagasaka K, Matsumoto Y, Wada-hiraike O, et al. Clinical significance of Gremlin 1 in cervical cancer and its effects on cancer stem cell maintenance. Oncol Rep. 2016; 35:3917. https://doi.org/10.3892/or.2015.4367. [ubMed]

10. Yin Y, Yang Y, Yang L, Yang Y, Li C, Liu X, Qu Y. Overexpression of Gremlin promotes non-small cell lung cancer progression. Tumour Biol. 2016; 37:2597-602. https://doi.org/10.1007/s13277-015-4093-8. [PubMed]

11. Ehata S, Yokoyama Y, Takahashi K, Miyazono K. Bidirectional roles of bone morphogenetic proteins in cancer: Another molecular Jekyll and Hyde? Pathol Int. 2013; 63:287-96. https://doi.org/10.1111/pin.12067. [PubMed]

12. Guinney J, Dienstmann $\mathrm{R}$, Wang $\mathrm{X}$, de Reyniès A, Schlicker A, Soneson C, Marisa L, Roepman P, Nyamundanda G, Angelino P, Bot BM, Morris JS, Simon IM, et al. The consensus molecular subtypes of colorectal cancer. Nat Med. 2015; 21:1350-6. https://doi. org/10.1038/nm.3967. [PubMed]

13. Karagiannis GS, Treacy A, Messenger D, Grin A, Kirsch R, Riddell RH, Diamandis EP. Expression patterns of bone morphogenetic protein antagonists in colorectal cancer desmoplastic invasion fronts. Mol Oncol. 2014; 8:1240-52. https://doi.org/10.1016/j.molonc.2014.04.004. [PubMed]

14. Deng H, Makizumi R, Ravikumar TS, Dong H, Yang W, Yang WL. Bone morphogenetic protein-4 is overexpressed in colonic adenocarcinomas and promotes migration and invasion of HCT116 cells. Exp Cell Res. 2007; 313:103344. https://doi.org/10.1016/j.yexcr.2006.12.020. [PubMed]

15. Lorente-Trigos A, Varnat F, Melotti A, Ruiz i Altaba A. BMP signaling promotes the growth of primary human colon carcinomas in vivo. J Mol Cell Biol. 2010; 2:31832. https://doi.org/10.1093/jmcb/mjq035. [PubMed]

16. Davis H, Raja E, Miyazono K, Tsubakihara Y, Moustakas A. Mechanisms of action of bone morphogenetic proteins in cancer. Cytokine Growth Factor Rev. 2016; 27:81-92. https://doi.org/10.1016/j.cytogfr.2015.11.009. [PubMed]

17. Jaeger E, Leedham S, Lewis A, Segditsas S, Becker M, Cuadrado PR, Davis H, Kaur K, Heinimann K, Howarth K, East J, Taylor J, Thomas H, et al. Hereditary mixed polyposis syndrome is caused by a $40-\mathrm{kb}$ upstream duplication that leads to increased and ectopic expression of the BMP antagonist GREM1. Nat Genet. 2012; 44:699703. https://doi.org/10.1038/ng.2263. [PubMed]

18. Pelli A, Väyrynen JP, Klintrup K, Mäkelä J, Mäkinen MJ, Tuomisto A, Karttunen TJ. Gremlin1 expression associates with serrated pathway and favourable prognosis in colorectal cancer. Histopathology. 2016; 69:831-8. https:// doi.org/10.1111/his.13006. [PubMed]

19. Davis H, Irshad S, Bansal M, Rafferty H, Boitsova T, Bardella C, Jaeger E, Lewis A, Freeman-Mills L, Giner FC, Rodenas-Cuadrado P, Mallappa S, Clark S, et al. Aberrant epithelial GREM1 expression initiates colonic tumorigenesis from cells outside the stem cell niche. Nat Med. 2014; $21: 62-$ 70. https://doi.org/10.1038/nm.3750. [PubMed] 
20. de Sousa E Melo F, Colak S, Buikhuisen J, Koster J, Cameron K, de Jong JH, Tuynman JB, Prasetyanti PR, Fessler E, van den Bergh SP, Rodermond H, Dekker E, van der Loos CM, et al. Methylation of cancer-stem-cellassociated Wnt target genes predicts poorprognosis in colorectal cancer patients. Cell Stem Cell. 2011; 9:476-85. https://doi.org/10.1016/j.stem.2011.10.008. [PubMed]

21. Marisa L, de Reyniès A, Duval A, Selves J, Gaub MP, Vescovo L, Etienne-Grimaldi MC, Schiappa R, Guenot D, Ayadi M, Kirzin S, Chazal M, Fléjou JF, et al. Gene Expression Classification of Colon Cancer into Molecular Subtypes: Characterization, Validation, and Prognostic Value. Kemp C, editor. PLoS Med. 2013; 10:e1001453. https://doi.org/10.1371/journal.pmed.1001453. [PubMed]

22. McCorry AM, Loughrey MB, Longley DB, Lawler M, Dunne PD. Epithelial-to-mesenchymal transition signature assessment in colorectal cancer quantifies tumour stromal content rather than true transition. J Pathol. 2018; 246:422-6. https://doi.org/10.1002/path.5155. [PubMed]

23. Calon A, Lonardo E, Berenguer-Llergo A, Espinet E, Hernando-Momblona X, Iglesias M, Sevillano M, PalomoPonce S, Tauriello DVF, Byrom D, Cortina C, Morral C, Barceló C, et al. Stromal gene expression defines poorprognosis subtypes in colorectal cancer. Nat Genet. 2015; 47:320-9. https://doi.org/10.1038/ng.3225. [PubMed]

24. Dunne PD, McArt DG, Bradley CA, O'Reilly PG, Barrett HL, Cummins R, O'Grady T, Arthur K, Loughrey MB, Allen WL, McDade SS, Waugh DJ, Hamilton PW, et al. Challenging the Cancer Molecular Stratification Dogma: Intratumoral Heterogeneity Undermines Consensus Molecular Subtypes and Potential Diagnostic Value in Colorectal Cancer. Clin Cancer Res. 2016; 22:4095104. https://doi.org/10.1158/1078-0432.CCR-16-0032. [PubMed]

25. Isella C, Terrasi A, Bellomo SE, Petti C, Galatola G, Muratore A, Mellano A, Senetta R, Cassenti A, Sonetto C, Inghirami G, Trusolino L, Fekete Z, et al. Stromal contribution to the colorectal cancer transcriptome. Nat Genet. 2015; 47:312-9. https://doi.org/10.1038/ng.3224. [PubMed]

26. Calon A, Espinet E, Palomo-Ponce S, Tauriello DVF, Iglesias M, Céspedes MV, Sevillano M, Nadal C, Jung
P, Zhang XHF, Byrom D, Riera A, Rossell D, et al. Dependency of colorectal cancer on a TGF- $\beta$-driven program in stromal cells for metastasis initiation. Cancer Cell. 2012; 22:571-84. https://doi.org/10.1016/j. ccr.2012.08.013. [PubMed]

27. Linnekamp JF, Hooff SRV, Prasetyanti PR, Kandimalla R, Buikhuisen JY, Fessler E, Ramesh P, Lee KAST, Bochove GGW, de Jong JH, Cameron K, Leersum RV, Rodermond $\mathrm{HM}$, et al. Consensus molecular subtypes of colorectal cancer are recapitulated in in vitro and in vivo models. Cell Death Differ. 2018; 25:616-33. https://doi.org/10.1038/ s41418-017-0011-5. [PubMed]

28. Kim HS, Shin MS, Cheon MS, Kim JW, Lee C, Kim WH, Kim YS, Jang BG. GREM1 is expressed in the cancerassociated myofibroblasts of basal cell carcinomas. PLoS One. 2017; 12:1-13. https://doi.org/10.1371/journal. pone.0174565. [PubMed]

29. Church RH, Ali I, Tate M, Lavin D, Krishnakumar A, Kok HM, Hombrebueno JR, Dunne PD, Bingham V, Goldschmeding R, Martin F, Brazil DP. Gremlin1 plays a key role in kidney development and renal fibrosis. Am J Physiol Renal Physiol. 2017; 312:F1141-57. https://doi.org/10.1152/ ajprenal.00344.2016. [PubMed]

30. Yoshihara K, Shahmoradgoli M, Martínez E, Vegesna R, Kim H, Torres-Garcia W, Treviño V, Shen H, Laird PW, Levine DA, Carter SL, Getz G, Stemke-Hale K, et al. Inferring tumour purity and stromal and immune cell admixture from expression data. Nat Commun. 2013; 4:2612. https://doi.org/10.1038/ncomms3612. [PubMed]

31. Schindelin J, Arganda-Carreras I, Frise E, Kaynig V, Longair M, Pietzsch T, Preibisch S, Rueden C, Saalfeld S, Schmid B, Tinevez JY, White DJ, Hartenstein V, et al. Fiji: an open-source platform for biological-image analysis. Nat Methods. 2012; 9:676-82. https://doi.org/10.1038/ nmeth.2019. [PubMed]

32. Rueden CT, Schindelin J, Hiner MC, DeZonia BE, Walter $\mathrm{AE}$, Arena ET, Eliceiri KW. ImageJ2: ImageJ for the next generation of scientific image data. BMC Bioinformatics. 2017; 18:529. https://doi.org/10.1186/s12859-017-1934-Z. [PubMed] 